\title{
Christian Prosperity Doctrine and Entrepreneurial Development of Nigeria: A Study of Selected Churches in Calabar, Nigeria
}

\author{
Bassey, Antigha Okon Ph.D \\ Lecturer, Department of Sociology, University of Calabar, \\ P.M.B. 1115, Calabar, Cross River State, Nigeria \\ Email: antigha2k4@yahoo.com \\ Charles, Joseph Okokon
}

Professor of Sociology and Social Anthropology Department of Sociology, University of Calabar, P.M.B. 1115, Calabar, Cross River State, Nigeria

\section{Ojua, Takim Asu Ph.D}

Senior Lecturer, Department of Sociology, University of Calabar, P.M.B. 1115, Calabar, Cross River State, Nigeria Email: taojua2007@yahoo.com

\section{Doi:10.5901/mjss.2014.v5n9p564}

\section{Abstract}

The study presents an empirical analysis of the influence of Christian prosperity doctrine on entrepreneurial development of Christians in Christian churches in Nigeria. It was a survey research where 800 subjects were examined from a study population of 111,286 subjects comprising Christians from four churches purposefully selected from the study area, Calabar. A questionnaire instrument comprising open and close ended questions on a four point rating scale was utilized to elicit information from respondents, which was analysed using Pearson product moment correlation test. A significant relationship was discovered between the teaching of Christian prosperity doctrine and the establishment of business ventures. It was discovered that not only the Christians who practice prosperity doctrine establish businesses, but the church organization also. It was recommended that government should improve infrastructure to boost Christian entrepreneurial effort, create regulatory and monitoring framework, as well as promote Christian evangelism in order to encourage entrepreneurial growth and development, among other things.

Keywords: Christian, prosperity doctrine, entrepreneurial development, churches, business ventures

\section{Introduction}

The teaching and doctrine of religion according to Watch Tower Bible and Tract Society (1990) should influence the personality and daily conduct of each believer. Thus, each person's conduct should normally be a reflection, to a greater or lesser degree, of his/her religious background. It is in this perspective that this study was designed to investigate the relationship existing between Christian prosperity doctrine and entrepreneurial development in Nigeria, as it relates to adherents generally.

Entrepreneurial development denotes the establishment of business ventures to stimulate the economy by increasing the level of business activities. A society in which the process of entrepreneurial development is on course is marked by the existence of micro, small and medium size enterprises, established and controlled by members of the society. Christianity is one out of the various religious practices in Nigeria, which includes Islam and African Traditional Religion being predominant among other sects and fraternities.

Christian Prosperity Doctrine is an element of Christian religion. This study was designed to identify the role which Christian prosperity doctrine plays in entrepreneurial development of Nigeria. 50.8\% of Nigeria's population are Christians, while Muslims are $47.8 \%$ and other religions constitute only 1.4\% (Wikipedia, 2013). From this statistics, Christianity is the predominant religion in Nigeria, especially in the southern part where Calabar the area of study is located. In view of this numerical strength of Christians, it was appropriate to examine if this Christian doctrine of 
prosperity influence the personality and daily conduct in terms of arousing business consciousness and establishment of business ventures.

Christian prosperity doctrine maintains that financial prosperity and success in business or personal life is an external evidence of God's favour on the believer. It is a growing Christian religious idea preached by pastors or ministers of Christian churches in contemporary times. Phiri and Maxwell (2007) explain that prosperity preachers inspire members to aim high, work hard, avoid vices, and improve their standard of living, and that proper teaching about prosperity leads to transformation. It is in this light that the study attempts to examine the impact of Christian prosperity doctrine on entrepreneurial development in Nigeria.

This study was timely, in view of the Federal Government of Nigeria's formulation and implementation of the Small and Medium Enterprises Development Policy, in order to ensure entrepreneurial development. The policy fundamentally focuses on promotion of business development, business financing, skill and job creation as well as poverty alleviation. In line with government policy objective, the study examines the effort of Christian churches in mobilizing their members to take advantage of governmental policy provisions, by engaging in economic activities, in terms of establishment of small and medium enterprises. In this direction, the study examines the contributions of Christian prosperity doctrine to entrepreneurial development of Nigeria.

\section{Problems of the Study}

Entrepreneurial development is the yearning of every developing economy. The important role of entrepreneurial development makes it symbolic in examining its relationship with other social phenomena, such as Christian prosperity doctrine. The Protestant doctrine of Calvanist Europeans provided the necessary environment for the rise of industrialization and capitalism in Europe. Weber (1958) was able to establish a relationship between Calvanist religion and capitalism or economic development in Western Europe, as protestant doctrine attacked time wasting, laziness and idle gossips.

Bearing the influence of Protestantism on the development of Europe, does the teaching of Christian prosperity doctrine encourage members of Christian churches to participate in entrepreneurial activities, by establishing business ventures? Churches are so many in Nigeria today and the percentage distribution of Christians in Nigeria demographic analysis as presented in Wikipedia (2013) makes it an important factor as a social indicator.

Considering the fact that Christian religion made inroad into Nigeria since the $18^{\text {th }}$ century over one hundred and fifty years now (Akinkusotewale, 1984), it was appropriate to examine the influence of Christian prosperity doctrine on entrepreneurial development in Nigeria. Specifically, the research study was structured to answer the vital question: What is the relationship between the teachings of Christian prosperity doctrine and the establishment of business or industrial outfits in Nigeria? This question reveals the research objective, which was: To determine if there is any relationship between the teachings of Christian prosperity doctrine and the establishment of business or industrial outfits in Nigeria.

\section{Conceptual Clarification and Literature Review}

Christian Prosperity Doctrine: This is a contemporary teaching in some Christian churches that prosperity, particularly financial prosperity, and success in personal life is external evidence of God's favour. This favour may be preordained, or granted in return for efficacious prayer or merry-making service in the church, such as donation to church work. It is not only about money, but about a whole life, including success in marriage, social status in society and good health. Christian prosperity doctrine is described by Ulmer (2007) as prosperity theology.

Prosperity theology is commonly a part of television evangelism carried out by charismatic and Pentecostal churches, but not exclusive to them, meaning that it also permeates orthodox churches. Church pastors preaching or teaching prosperity doctrine make the claim that God wants Christians to be "abundantly" successful in every way (Karjala, 2007). The general teaching to Karjala (2007) is that when believers give their hard-earned wages to the "anointed" servants (ministers who preach and teach the doctrine), a spiritual principle is enacted guaranteeing that the financial offerings (or seeds) of the contributors will be multiplied and returned to them.

Prosperity doctrine is based upon a belief in the unified power of faith and the tongue. Faith is a confession and word spoken in faith come to pass. Consequently, reality is created with the words of our mouths. Thus, the basis of prosperity doctrine is "what I confess, I possess". In this regard, there exists for Christians supernatural blessings for their complete prosperity. Karjala (2007) also noted Christians' inward and spiritual transformation will naturally result in an outward working that takes effect in every area of life.

Fundamental Bible portions which preachers utilize in support of Christian prosperity theology include: 
You say, I am rich, and have become wealthy, and have need of nothing, and you do not know that you are wretched and miserable and poor and blind and naked, I advised you to buy from me gold refined by fire, that you may become rich, and white garments, that you may clothe yourself and that the shame of your nakedness may be revealed, and eyes salve. To anoint your eyes, that you may see (Revelation 3: 17-18).

It is expected that as members sow seed in terms of offering in churches, so will they be endowed with riches, wealth and prosperity from Heaven. Another inspiring scripture which is used in support of prosperity doctrine is 3 John 1 : 2 "Beloved, I wish above all things that thou mayest prosper and be in health even as thy soul prospereth". Pride (2006) however argued that "prosper" does not mean "wealth", since the next words says "even as thy soul prospereth". Souls do not receive material wealth, although they can become spiritually rich in faith. Therefore, this verse as articulated above inferred prosperity to transient material wealth and include all round buoyancy of the human nature and personality.

Critiques of Christian prosperity doctrine maintain that prosperity doctrine (give and take scheme) completely eliminates the selfless, sacrificial aspect of giving associated with the early Christians. No one mentioned in the New Testament that those who made sacrifices to support the work of God inherited any kind of material wealth as a result. Nor the accumulation of wealth the heart desire of early believers. Scholars like Pride (2006) explain that prosperity doctrine exists and thrives by the greedy nature that most people possess and that many people are not content to receive a heavenly reward for their giving. Considering these critical standpoints, this study examines the effect of prosperity doctrine on entrepreneurial development in terms of establishment of business ventures, as well as the growth and development of such ventures as parameters for assessing general socio-economic development.

\section{Entrepreneurial Development}

Entrepreneurial development involves the establishment of business ventures to stimulate the economy by increasing the level of business activities (Hisrich, Peters and Shepherd, 2007). This is guided by the spread of entrepreneurial consciousness and spirit which refers to the feelings of the desire to pool resources together under personal control and the inner drive for independence as a result of difficulties encountered in working for someone else, and the motive of need for personal achievement.

Hisrich, Peters and Shepherd (2007) consider entrepreneurship as the process of creating something new in value, by devoting the necessary time and effort, assuming the accompanying financial, psychic and social risk, and receiving the resulting rewards of monetary, personal satisfaction and independence. Consequently, any one in any profession and vocation can be considered as an entrepreneur. Ely and Hess (1937) in analyzing the role of entrepreneurship in socioeconomic development maintained that it involves more than just increasing per-capita output or income; it involves also initiating and constituting change in the structure of business and society. Such capital created, expands the capacity for growth, resulting in development. Although Ely and Hess (1937) did not reflect religious affiliation of the entrepreneurs, the gap so created necessitates this study on Christian prosperity doctrine and entrepreneurial development.

\section{Establishment of Business Ventures and Prosperity Doctrine}

Business ventures are organisations, firms or companies established by an individual or group of people in order to carry out work, which may be: buying and selling, services, or production, to generate profit and satisfy the desire of the owner(s). Business ventures are established for the sole purpose of profit maximization. Ukah (2007) in an empirical study of Pentecostal churches in Nigeria and Cameroon noted the involvement of church members in running large business empires as top management personnel, owners and at times financiers (shareholders).

The study of Ukah (2007) also noted the use of media by Pentecostal churches to mobilise financial resources which they direct at business empire building. Such church business empires include healthcare institutions, transport services, hospitality ventures and educational institutions. Churches are also involved in cottage industries like: pure water, printing press, paper mills etc. This study focuses specifically on church members and the effect of prosperity doctrine on them in terms of stimulating them to engage in establishment of business ventures. This is based on the premise that widespread establishment of business ventures will stimulate socio-economic growth and development.

Considering religion as one of the factors that are likely to influence individual attitude and behavior, it becomes necessary to investigate Christian prosperity doctrine and its impact on entrepreneurial development by comparing the assumptions of prosperity doctrine of "give to get more" with the fundamental principle of entrepreneurship which include: risk, sacrifice and profit maximization, explained above. It is appropriate to critically examine the compatibility of 
prosperity doctrine in terms of its scriptural foundation and its impact on entrepreneurial conduct of Christians.

\section{Theoretical Framework}

The theory selected to guide investigation was the n-achievement theory of David McClelland. The major hypothesis of the theory is that "a nation with a generally high level of n-Achievement will produce more energetic entrepreneurs, who in turn produce rapid economic development" (McClelland, 1963; Offiong, 1980). This theory attempts to establish a correlation between desire for entrepreneurial achievement and economic development, on the cardinal assumption that "it is value, not motives or psychological forces that determine ultimately the rate of economic and social development" (McClelland, 1963).

According to McClelland (1963), social characteristics such as class, religion and industrial occurrences, affect motivational levels primarily as they affect the family, or more specifically the values and child-rearing practices of the parents. McClelland (1963) set standards for measuring n'Achievement in terms of high and low scores, stating that people with high achievement motives would seek out situations in which they would get achievement satisfaction. Entrepreneurs differently establish business ventures which provide them with satisfaction in their daily life.

McClelland (1963) noted that a number of people with high n'Achievement happen to be present in a given culture, and at a given time things would start to change. The people with high n'Achievement will start doing things in a better way and also differently by trying to get achievement satisfaction out of desire to make money, please themselves, or other personal gains, which might be converted into an activity in which standards of excellence were defined and pursued in their own right. Among such activities include the pursuit of business interest and profit which are by themselves entrepreneurial. Christian religion is a cultural area with the prosperity doctrine as a basic cultural element which provides ideological support for entrepreneurial growth and development.

This theory is criticized by Offiong (1980), who rejects McClelland's identification of pre-industrial and undeveloped societies with low achievement-orientation. Collaborated by Barrette (1968) that such assumption is invalid in view of the demonstration of high n'Achievement value in traditional Igbo society prior to western contact. McClelland's conclusion that those with high scores were entrepreneurial types and those with low scores not entrepreneurial, proved that "it is men and their deepest concerns that shape history" (McClelland, 1961). It is this conclusion that draw the usefulness of McClelland's theory as a guide to this investigation, as seen in the linkage established in the explanations above. This study investigates entrepreneurial attitude of Nigerians, if they are guided by n'Achievement, embedded in the prosperity doctrine being an element of the culture of Nigerian Christians. It is within this limits of explanation that the theory is adopted to explain issues that are critically discussed in this study.

\section{Methodology}

The study employed the survey research design of an ex-post facto type. The independent variable in the study was Christian prosperity doctrine, while the dependent variable was entrepreneurial development, in terms of establishment of business ventures. The study population comprises the entire membership strength of the four churches selected for the study, being 111,286 subjects.

Sample of 800 subjects were purposively selected from the population, divided into four clusters representing the four churches. Each cluster consisted of 200 respondents. The respondents were selected accidentally from each cluster during their meeting.

Table I: Sample and Population of Study

\begin{tabular}{|c|l|c|c|l|c|}
\hline S/N & Churches/Cluster & Population & Sample & Classification & Percentage \\
\hline 1 & Catholic & 47,118 & 200 & Orthodox & $25 \%$ \\
2 & The Apostolic & 52,468 & 200 & Pentecostal & $25 \%$ \\
3 & Living Faith & 6,700 & 200 & National charismatic & $25 \%$ \\
4 & Christian Central Chapel & 5,000 & 200 & Indigenous charismatic & $25 \%$ \\
\hline & Total & 111,286 & 800 & & $100 \%$ \\
\hline
\end{tabular}

Sources: Catholic Archdiocese of Calabar, 2008; The Apostolic Church Record, 2009; www.emmahisong.com, 2009; Field survey, 2009 
Classification of churches adopted in Table I above follows Karjala (2007) classification of Christian churches. A set of structured questionnaires with open ended section were administered. The instrument follows a four point rating scale Strong Agree $(S A)=4$ points, Agree $(A)=3$ points, Disagree $(D)=2$ points, Strongly Disagree $(S D)=1$ point.

Other methods utilized for the study were Focus Group Discussion (FGD) and In-depth interview (IDI), which were qualitative techniques adopted to verify the findings of the survey method. Four FGDs were conducted, each per cluster. Each FGD comprised of eight participants from business class, civil servants, unemployed, artisans, nominated by the church. Four In-depth Interviews were also conducted in which a knowledgeable respondent was interviewed in each of the four churches purposively selected for the study.

The coding for analysis in the study was derived electronically. Pearson product moment correlation coefficient was utilized as appropriate test statistics to the hypothesis guiding the study. Significance level was 0.05 .

Null hypothesis $(\mathrm{HO})$ : There is no significant relationship between the teaching of Christian prosperity doctrine and the establishment of business ventures by Christians as an indicator of entrepreneurial development.

Alternative Hypothesis (Hi): There is a significant relationship between the teaching of Christian prosperity doctrine and the establishment of business ventures by Christians as an indicator of entrepreneurial development.

\section{Description of Study Area}

Calabar is the capital of Cross River State, located at the south-eastern extreme of Nigeria. Calabar comprises two local government areas namely: Calabar Municipality with population of 179,392 and Calabar South with population of 191,630 (Official Gazette, 2007). There are three indigenous ethnic groups in Calabar - the Efiks, Efuts and Quas. Calabar is highly heterogeneous with people from Ibibio, Annang, Hausa, Yoruba, Igbo, Boki, Ijaw, Tiv and foreign nationals residing therein.

Calabar started participating in international trade and commerce right from the time of slave trade as noted by Noah (1980), in the $17^{\text {th }}$ century. At the abolition of slave trade in Calabar in 1842, Calabar continued as a centre of the emerging mercantilist trade. It is one of the African towns in which socio-economic transformation that changed an agrarian society commenced over two centuries ago (Noah, 1980).

The European missionaries first arrived Old Calabar in 1846 on the invitation of the kings of Old Calabar. Today, there are so many churches in Calabar. Over $97 \%$ of the residents are Christians (Akinkusote, 1984). The city of Calabar is not left out in the phenomenal growth and proliferation of churches, scattered everywhere in the city. It is the emerging entrepreneurial and industrial growth of Calabar from agrarian traditional stage to industrial stage and the fact that the inhabitants are predominantly Christians that motivated the consideration of Calabar as an appropriate study area to investigate if there is any relationship existing between Christian prosperity doctrine and entrepreneurial development.

Consequently, four Christian churches deeply rooted in the city were selected, namely: Catholic, The Apostolic, Living Faith and Christian Central Chapel International. Calabar as a diocese, is the archdiocesan capital of one of the nine provinces of the church in Nigeria. The Apostolic is a Pentecostal denomination with headquarters in Britain. The Apostolic church spread from Calabar to entire eastern Nigeria and the Cameroon. Living Faith church is a national charismatic church with large congregation and branches spread over Calabar. Christian Central Chapel is indigenous to Calabar with large congregation and membership in the city. Despite slight differences in fundamental doctrine, all the churches believe in Christ as Son of God, saviour and redeemer of mankind. Elements of prosperity doctrine are preached by clergymen in all Christian churches, which purposively provoked their selection for study.

\section{Data Presentation}

Data obtained from field survey were presented in tables. The tables represent demographic data about respondents.

Table 2: Sex Distribution of Respondents

\begin{tabular}{|l|c|c|c|c|c|c|}
\hline Sex & Catholic & Apostolic & Living Faith & CCCI & Frequency & Percentage \\
\hline Male & $128(16.0)$ & $131(16.4)$ & $143(17.88)$ & $126(15.75)$ & 528 & 66.0 \\
Female & $72(9.0)$ & $69(8.6)$ & $57(7.1)$ & $74(9.3)$ & 272 & 34.0 \\
\hline Total & $\mathbf{2 0 0}$ & $\mathbf{2 0 0}$ & $\mathbf{2 0 0}$ & $\mathbf{2 0 0}$ & $\mathbf{8 0 0}$ & 100.00 \\
\hline
\end{tabular}

Source: Field Survey, 2009 
Table 2 reveals that 528 respondents were males, representing 66\%, while 272 representing $34 \%$ were females. This was contrary to a widely held belief that females are more than male in churches as indicated by Akinkusote (1984). Observations during the survey was that females were relatively unwilling to neither accept the questionnaire instrument nor participate in the FGD, than male.

Table 3: Educational attainment of Respondents

\begin{tabular}{|l|c|c|c|c|c|c|}
\hline Educational level & Catholic & Apostolic & Living Faith & CCCI & Frequency & Percentage \\
\hline FSLC & $17(2.13)$ & $24(3.0)$ & $9(1.16)$ & $14(1.75)$ & 64 & 8.0 \\
SSCE & $103(12.9)$ & $94(11.75)$ & $85(10.6)$ & $102(12.75)$ & 384 & 48.0 \\
ND/NCE & $45(5.6)$ & $41(5.1)$ & $63(7.88)$ & $26(3.3)$ & 175 & 21.9 \\
HND/B.SC & $12(1.5)$ & $13(1.6)$ & $8(1.0)$ & $15(1.9)$ & 48 & 6.0 \\
M.Sc. & $18(2.3)$ & $21(2.6)$ & $23(29)$ & $18(2.3)$ & 80 & 10.0 \\
Ph.D & $5(0.6)$ & $7(0.9)$ & $12(1.5)$ & $25(3.13)$ & 49 & 6.1 \\
\hline Total & $\mathbf{2 0 0}$ & $\mathbf{2 0 0}$ & $\mathbf{2 0 0}$ & $\mathbf{2 0 0}$ & $\mathbf{8 0 0}$ & $\mathbf{1 0 0 . 0 0}$ \\
\hline
\end{tabular}

Source: Field Survey, 2009

Table 3 shows that respondents were literate and understood the questions in the instrument and can provide appropriate responses as were required of them. It also shows that members of Christian churches in Calabar are educated and based on their educational attainment, understood the scripture and its teachings, including prosperity doctrine. Similarly, respondents based on their educational attainment were conversant with the instrument of data collection used for this study.

Table 4: Distribution of Respondents by Occupation

\begin{tabular}{|l|c|c|c|c|c|c|}
\hline Occupation & Catholic & Apostolic & Living Faith & CCCI & Frequency & Percentage \\
\hline Civil servants & $57(7.13)$ & $48(6)$ & $52(6.5)$ & $59(7.38)$ & 216 & 27 \\
\hline Private sector employee & $19(2.4)$ & $27(3.38)$ & $36(4.5)$ & $28(3.5)$ & 110 & 13.8 \\
\hline Business owner/ entrepreneur & $32(4.0)$ & $24(3.0)$ & $34(4.3)$ & $41(5.13)$ & 131 & 16.4 \\
\hline Unemployed & $14(1.75)$ & $20(2.5)$ & $17(2.13)$ & $14(1.75)$ & 65 & 8.1 \\
\hline Student & $58(7.28)$ & $37(4.63)$ & $43(5.38)$ & $48(6.0)$ & 186 & 23.3 \\
\hline Others & $20(2.5)$ & $44(5.5)$ & $18(2.25)$ & $10(1.25)$ & 92 & 11.5 \\
\hline Total & $\mathbf{2 0 0}$ & $\mathbf{2 0 0}$ & $\mathbf{2 0 0}$ & $\mathbf{2 0 0}$ & $\mathbf{8 0 0}$ & $\mathbf{1 0 0 . 0 0}$ \\
\hline
\end{tabular}

Source: Field Survey, 2009

Table 4 shows that respondents were engaged in one activity or the other including students. This indicates that significant number of respondents have goal to attain in life and aspire towards success and goal achievement, which are all entrepreneurial elements. 16.4 percent were purely entrepreneurs, while 326 (40.8\%) were employees working towards achievement of organizational or industrial optimization.

Table 5: Qualitative Research Table

Focus Group Discussion Demographic Table

\begin{tabular}{|c|c|c|c|c|c|}
\hline & & Catholic & Apostolic & Living Faith & $\mathrm{CCCl}$ \\
\hline \multirow{2}{*}{ Sex } & Male & $5(62.5)$ & $6(75.0)$ & $4(50.0)$ & $5(62.5)$ \\
\hline & Female & $3(37.5)$ & $2(25.0)$ & $4(50.0)$ & $3(37.5)$ \\
\hline \multirow{2}{*}{ Education } & FSLC-NCE & $2(25.0)$ & $7(87.5)$ & $1(12.5)$ & $3(37.5)$ \\
\hline & Degree \& above & $6(75.0)$ & $1(12.5)$ & $7(87.5)$ & $5(62.5)$ \\
\hline \multirow{2}{*}{ Occupation } & Business owner & $4(50.0)$ & $2(25.0)$ & $5(62.5)$ & $6(75.0)$ \\
\hline & Employee & $4(50.0)$ & $6(75.0)$ & $3(37.5)$ & $2(25.0)$ \\
\hline \multicolumn{6}{|c|}{ Indepth Interview } \\
\hline \multicolumn{2}{|c|}{ Denomination } & Catholic & Apostolic & Living Faith & $\mathrm{CCCl}$ \\
\hline \multicolumn{2}{|c|}{ Sex } & Male & Male & Female & Male \\
\hline \multicolumn{2}{|c|}{ Level of education } & B.Sc. & $\mathrm{CE}$ & M.Sc. & HND \\
\hline \multicolumn{2}{|c|}{ Occupation } & Business & Trader & Public sector employee & Building contractor \\
\hline
\end{tabular}

Source: FGD/IDI (2009) 
Table 5 above shows that participants in FGD and IDI were all literate. In the four FGD with 8 participants each, with a total of 32 participants in all, male were 20 (62.5) and female 12 (37.5). As in the survey, male were more than female implying that male are more receptive to academic exercise than female. The domination of business owners and workers proved that participants understood the issue being entrepreneurs.

\section{Test of Hypothesis}

HO: There is no significant relationship between the teaching of Christian prosperity doctrine and the establishment of business ventures by Christians as an indicator of entrepreneurial development.

The dependent variable was establishment of business ventures, while the independent variable was the teaching of Christian prosperity doctrine. A Pearson product moment correlation coefficient test was performed to analyse the interrelationship between the dependent and independent variables, at 0.05 level of significance, where degree of freedom was 798. In the analysis, " $X$ " represents data from statement 17 while " $Y$ " represents data from statement 15 in the questionnaire instrument.

Statement 17: Practice of prosperity teaching guides me to living a businesslike life in my career or vocation.

Statement 15: I am encouraged to start business because of my belief that God destined me to succeed

Table 6: Pearson product moment correlation coefficient matrix of $x$, $y$ variables $(n=800)$

\begin{tabular}{|l|c|c|c|c|c|c|}
\hline Variables & $\sum X \sum Y$ & $\sum X^{2}$ & $\sum X Y$ & $D f$ & $r$-cal & r-critical 0.05 \\
\hline$X Y$ & 12824 & 26342 & 368543 & 798 & 0.94 & .062 \\
\hline
\end{tabular}

Significant level $r=.05$

Source: Author's statistical analysis (2009)

Decision: Since obtained $r(0.94)$ was greater than critical value (.062), the null hypothesis was rejected because the result was significant and closer to +1 . Therefore, the alternative hypothesis was invoked thus: There is significant relationship between the teaching of Christian prosperity doctrine and the establishment of business ventures as an indicator of entrepreneurial development.

\section{Discussion of Finding}

The study indicates a significant relationship existing between Christian prosperity doctrine and the establishment of business ventures. Though no general acceptance was given in the qualitative method (FGD and IDI) that there is a central doctrine in Christiandom called "Christian Prosperity Doctrine", there existed various elements of prosperity in sermons, fundamental belief and teachings of churches in which survey was conducted. In FGD at The Apostolic Church, it was gathered that:

Prosperity doctrine is a coinage of tele-preachers. To "sow seed" for example is not found in the Bible. The people are out to make money and they work upon the psyche of the people, because when people hear this prosperity, they jump. But when this does not happen, they think God is a liar, which is not so. (The Apostolic Church FGD, 2009).

Despite the above observation, participants also maintained that prosperity comes from God and when covenant principles are followed strictly, one will experience prosperity.

This was the view of participants at FGD conducted at Living Faith Church. One participant at FGD, quoting the founder of Living Faith Church, said "he is handling the church as a business because Jesus said, "He is doing His father's business". The church today is shifting towards providency so that the funds realized can be used to help the under-priviledgd in our midst to be on their own. This view of a Christian leader shows that the church is in business, likewise members of the church. The following Living Faith Church doctrines were enumerated as covenant principles: Tithing, giving to neighbnours, covenant fathers (clergy) and parent, relating well with everybody, service to God and man and not giving with "intent" (FGD: Living Faith Church).

Respondents were required to state other factors they considered to be responsible for the entrepreneurial growth of Calabar in-view of the emergence of companies, industries and diversity of production outfits, in open-ended question 
in the questionnaire instrument, FGD and IDI, the summary of their responses are:

1. Tourism drive of the state government

2. Government policy formulation and implementation in areas of poverty alleviation and free trade zone.

3. Activities of international agencies and civil society organisations (NGOs)

4. Urban renewal and development activities of state government in areas of road construction and provision of infrastructure.

5. Foreign investment due to the enabling socio-economic conduciveness.

On factors militating against rapid entrepreneurial and socio-economic development, the summary of responses were as follows: Lack of credit facility for small, micro and medium business development; Economic instability in terms of current depression popularly termed "melt-down"; Multiple tax system in the state such as from State Internal Revenue, Calabar Urban Development, Local Government and other agents for rates and levies collection; High cost of rent for business premises; General low income of public/civil servants; Lack of interest in long term investment; Poor energy supply; Inadequate training, skill and knowledge of entrepreneurial development; Insecurity occasioned by area-boys and armed robbers; Unregulated multiplication (proliferation) of churches; and Political instability which causes frequent changes in macro-economic policies and indicators

In stating other sources of prosperity respondents considered may influence business development, summary include: ritual, sharp practices like corruption, fraud, excessive profit making, smuggling, and assignment in churches and spiritual homes. These were considered ungodly acts, which no true Christian should be involved in, as such are forbidden by the scripture.

\section{Conclusion and Recommendations}

The study was aimed at finding out the effect of Christian prosperity doctrine on entrepreneurial development. The cardinal goal of any church is to lead members to salvation by preparing them for heaven. Christians are prepared through teachings from the scripture which include prosperity doctrine. In Luke 12: 31, Christians are advised to "seek first the kingdom of God and all other things shall be added unto them," including prosperity. The interest in entrepreneurial development was occasioned by government policy on enterprises development, industrialization and socio-economic development. The study reveals a significant correlation between Christian prosperity doctrine and entrepreneurial development.

The practice of Christian prosperity doctrine by church members motivated them to be business conscious and to engage in various entrepreneurial activities which ginger individual and societal socio-economic development especially of Calabar dwellers. The study confirms the findings of Lavines, Strangman and Unterberger (1994), display of high n'achievement among Igbos who were predominantly Christians, as well as Weber (1958) postulates that Christians possess high n'achievement and discipline which resulted in capital formation. Therefore, any one with low entrepreneurial drive who desires to go into entrepreneurship should accept and follow Christian teaching and faith in God as a potent source of prosperity.

The study recommended that government should improve infrastructure in areas of good roads, communication, transportation and power supply to ensure favourable environment for business development. A Ministry of Religious Affairs should be created to monitor activities of churches to bring it in line with general developmental goal of the state. To avoid exploitation of the utility of prosperity doctrine by fraudsters in Christendom, any church not duly registered must be compelled to do so and those registered must be monitored in terms of an external audit requirement. Finally, clergymen must be regulated to declare their assets to prevent the misappropriation of excess church fund for personal use at the expense of the church organization and generality of members.

\section{References}

Akinkusote, A. (1984) Yearbook of Nigerian Churches, Ibadan: Akin Akinniola Associates

Barrette, S. (1968) The achievement factor in Igbo receptivity to industrialization. The Canadian Review of Sociology and Anthropology, 5(20), 16-29

Bassey, A. (2010) "Christian Prosperity Doctrine and Entrepreneurial Development in Nigeria: A study of selected churches in Calabar, Cross River State, Nigeria" A Doctorial Dissertation, Department of Sociology, University of Calabar, Calabar (unpublished)

Ely, R. and Hess, R. (1937) Outlines of Economics (6 $6^{\text {th }}$ ed.) New York: Macmillan

Hisrich R., Peters M. and Shepherd, D. (2007) Entrepreneurship, New Delhi: Tata McGraw-Hill

Holy Bible (2007) Chicago: The Bible League

Karjala, K. (1953) Foundations of Christianity. New York: Russell Books 
McClelland, D. (1961) The Achieving Society. New York: Irvington Publishers

McClelland, D. (1963) "Motivational Patterns in South East Asia with Special Reference to the Chinese Case", Journal of Social issues, 29(1), 147-166

Noah, M. (1980) Old Calabar: The City State and the Europeans, Calabar: Scholars Press

Official Gazette of Federal Republic of Nigeria (2009) "Legal Notice on Publication of 2006 Census Final Result, No. 2, Vol. 96, Abuja: The Federal Government Printers

Offiong, D. (1980) Imperialism and Dependency, Enugu: Fourth Dimension Publishers

Phiri, M. and Maxwell, F. (2007) Keys to Financial Excellence. New York: Collins

Pride, L. (2006) Quotes by teachers of the prosperity doctrine, Lagos: Essek Publishers

Ukah, A. (2007) Prety and Profit: Accounting for Money in West African Pentecostalism (Part 1). Journal of Development, Enlightenment and Law, 48 (3 \& 4), 621-632

Ulmer, F. (2007) The Bible and Prosperity Lifestyle of Televangelist. New York: Games Press

Watch Tower Bible \& Tract Society (1990) Mankind's search for God. Brooklyn: International Bible Students Association

Weber, M. (1958) The Protestant Ethic and the Spirit of Capitalism. New York: Charles Scribner

Wikipedia (2013) "Religion in Nigeria" www.en.wikipedia.org/wiki/religion.in.Nigeria. Retrieved 18/7/13 